DOI: https://doi.org/10.18371/fp.4(36).2019.190230

УДК 65.012 .32

\title{
ВПЛИВ КОРПОРАТИВНОЇ КУЛЬТУРИ НА ЕФЕКТИВНІСТЬ ДІЯЛЬНОСТІ ОРГАНІЗАЦІї
}

\author{
ЛИТВИН Олена Євгенівна \\ Кандидат економічних наук, \\ Дочент кафедри економіки та менеджменту \\ Інститут банківських технологій та бізнесу \\ ДВНЗ «Університет банківської справи», Украӥна \\ e-mail: kafedra_mm@ukr.net

\section{ГАЛИЦЬКА Ольга Вікторівна \\ Студентка магістратури, Інститут банківських технологій та бізнесу ДВНЗ «Університет банківської справи», Украӥна e-mail: www.galickaya@gmail.com}

Анотація. Розглянуто теоретичні засади формування корпоративної культури організації, розкрито основні типи корпоративних культур, проаналізовано фактори впливу на корпоратину культуру компанії. Досліджено вплив корпоративної культури на ефективність діяльності компанії «Nestle». Виділено проблеми, які виникають в процесі становлення корпоративної культури як такої.

Ключові слова: Nestle, корпоративна культура, навчання, персонал.

Постановка проблеми. Сучасна економіка, що постійно еволюціонує та розвивається, вимагає від компаній бути більш інноваційними та такими, що постійно впроваджують зміни. Посилена конкуренція на всіх ринках збуту вибудовує такі вимоги до компаній, що вони вимушені боротися за своїх клієнтів. У таких умовах для кожної компанії стає необхідним вдало
Аннотация. Рассмотрено теоретические основы формирования корпоративной культуры организации, раскрыты основные типь корпоративных культур, проанализированы факторы влияния корпоративной культуры на эффективность деятельности компании «Nestle». Также выделены проблемы, которые возникают в прочессе становления корпоративной культуры как таковой.

Ключевые слова: Nestle, корпоративная культура, обучение, персонал.

комбінувати потреби клієнтів та потреби власних працівників. Саме через те, корпоративна культура $\epsilon$ чи не єдиним способом вирішення проблеми налагодження комунікації всередині колективу та вибудовування системи спільних цілей. Мінливі тенденції науково-технічного прогресу - від пріоритету технічної спрямованості до телекомунікацій, біотехнологій, інфор- 
маційних технологій, генної інженерії - змушують підприємство змінювати акцент своєї виробничо-господарської діяльності. Про низький рівень корпоративної культури на сьогоднішній день говорить не тільки використання фізично і морально застарілих технологій у виробничому процесі, але $\mathrm{i}$ «морально застарілі методи управління персоналом, організації технологічних процесів і управління підприємством і т.д.» [1].

Аналіз останніх досліджень і публікацій. Вплив корпоративної культури на підвищення конкурентоспроможності досліджували такі науковці як Портер М., Пітерс Т., Хенді С., Малик I., Язвінська I., Олійник Т., Гриненко А., Апостолюк О.

Метою статті $\epsilon$ аналіз стану формування корпоративної культури на прикладі компанії «Nestle», дослідження специфіки та проблем корпоративної культури та методів підвищення ефективності діяльності компанії шляхом покращення стану корпоративної культури.

Виклад основного матеріалу. Термін "корпоративна культура" з'явився

у XIX ст. Він був сформульований німецьким фельдмаршалом Мольтке, який використовував його, характеризуючи взаємини в офіцерському середовищі [2]. Згодом це поняття поширилося і на інші сфери, і зараз ні у кого не виникає сумнівів з приводу значущості корпоративної культури для успішного функціонування i процвітання будь-якої організації.

Корпоративна культура включає цілий ряд компонентів:

- уявлення про місію організації;
- ціннісні установки;

- моделі поведінки;

- стиль керівництва організацією;

- діюча система комунікації;

- норми ділового спілкування між членами колективу і з клієнтами;

- шляхи вирішення конфліктів;

- прийняті в організації традиції $\mathrm{i}$ звичаї;

- символіка організації.

Аналізуючи типи корпоративної культури, дослідники виокремлюють певну "об'єднуючу" теоретичну схему, в яку б укладалися основні підходи до вивчення феномену корпоративної культури, не нівелюючи при цьому цілісності кожної позиції.

Досить цікавою й корисною видається схема чотирьох типів корпоративної культури (Камерон і Квін):

1. Кланова культура. Організація тримається на відданості та традиціях, роблячи акцент на довгостроковій користі удосконалення особистості й надає великого значення високій мірі згуртованості колективу та моральному клімату.

2. Адхократична культура. Сутністю організації $є$ відданість експериментуванню й новаторству 3 діяльністю на "передньому рубежі", а успіхом вважається - виробництво унікальних нових продуктів та/або послуг.

3. Ієрархічна культура $є$ дуже формалізованим і структурованим місцем роботи, де критично важливо підтримування повільного ходу діяльності організації, яку об'єднують формальні правила й офіційна політика.

4. Ринкова культура, за якої організація, що орієнтована на результати, піклується передусім про виконання поставленої мети. Співробітники кон- 
курують між собою, а керівники - тве- досягненні мети - перемоги [3].

рді, суворі та вимогливі конкуренти в

Таблиця 1

Функції корпоративної культури

\begin{tabular}{|c|c|c|}
\hline № & Функція & Опис \\
\hline 1 & Інформаційна & полягає в передачі соціального досвіду \\
\hline 2 & Пізнавальна & $\begin{array}{l}\text { націлена на пізнання і засвоєння принципів культури на стадії адап- } \\
\text { тації працівника до організації i, таким чином, сприяє його включен- } \\
\text { ню у життя колективу }\end{array}$ \\
\hline 3 & Нормативна & адже культура встановлює норми прийнятної поведінки в організації \\
\hline 4 & Регулююча & $\begin{array}{l}\text { за допомогою неї відбувається порівняння реальної поведінки люди- } \\
\text { ни або групи до прийнятої в організації нормами }\end{array}$ \\
\hline 5 & Ціннісна & культура також впливає на світогляд людини \\
\hline 6 & Комунікативна & $\begin{array}{l}\text { через цінності, прийняті в організації, норми поведінки та інші } \\
\text { елементи культури забезпечується взаєморозуміння працівників та їх } \\
\text { взаємодія }\end{array}$ \\
\hline 7 & Охоронна & культура служить бар'єром для проникнення небажаних тенденцій \\
\hline 8 & Інтегруюча & $\begin{array}{l}\text { прийняття корпоративної культури формує спільність людей і вони } \\
\text { відчувають себе частиною єдиної системи }\end{array}$ \\
\hline 9 & Заміщуюча & $\begin{array}{l}\text { сильна культура дозволяє знизити потік формальних наказів і } \\
\text { розпоряджень }\end{array}$ \\
\hline 10 & Мотиваційна & $\begin{array}{l}\text { прийняття культури зазвичай створює додаткові можливості для лю- } \\
\text { дини і навпаки }\end{array}$ \\
\hline 11 & $\begin{array}{l}\text { Освітня і роз- } \\
\text { виваюча }\end{array}$ & $\begin{array}{l}\text { оволодіння культурою створює додаткові знання і позитивно впливає } \\
\text { на її діяльність }\end{array}$ \\
\hline 12 & $\begin{array}{l}\text { Управління } \\
\text { якістю }\end{array}$ & $\begin{array}{l}\text { з плином часу в культурі залишаються найбільш ефективні складові, } \\
\text { а всі негативні зникають }\end{array}$ \\
\hline 13 & $\begin{array}{l}\text { Формування } \\
\text { іміджу }\end{array}$ & $\begin{array}{l}\text { клієнти, відвідувачі та інші контрагенти не знайомі з офіційними до- } \\
\text { кументами, вони бачать зовнішню сторону фірми і це створює її об- } \\
\text { раз }\end{array}$ \\
\hline
\end{tabular}

Джерело: розроблено авторами на основі [3]

Модель Г. Харрісона розрізняє чотири типи корпоративної культури. Для аналізу він вибрав процес розподілу влади, ціннісні орієнтації особистості, відношення індивіда в організації, структуру організації і характер іiі діяльності на різних етапах еволюції. Такі моделі корпоративної культури рідко зустрічаються в чистому вигляді, але більшість організацій ближче всього за своєю культурою до якої-небудь 3 них:
- корпоративна культура, орієнтована на роль;

- корпоративна культура, орієнтована на завдання;

- корпоративна культура, орієнтована на людину;

- корпоративна культура 3 орієнтацією на владу [4].

Наразі, у менеджменті виділяють багато різноманітних підходів до типології. Але, у зв'язку з тим, що таке поняття як «корпоративна культура» почало досліджуватися ще в XX сто- 
літті, сьогодні деякі класичні моделі вже втратили свою актуальність. Тенденції розвитку інтернет-бізнесу сформували нові типи організаційних культур.

Типи корпоративних культур у сучасному бізнесі:

1. «Рольова модель». Тут взаємовідносини будуються на правилах $\mathrm{i}$

розподілі обов'язків. Кожний співробітник виконує свою роль маленького гвинтика у великому механізмі. Характерна риса - наявність чіткої ієрархії, строгих посадових інструкцій, правил, дрес-коду, формальних комунікацій.

2. «Dream Team». Командна модель корпоративної культури, у котрій немає ні посадових інструкцій, ні конкретних обов'язків, ні дрес-кодів. Ієрархія влади горизонтальна - підлеглих нема, є лише рівноцінні гравці однієї команди. Такий тип культури $\epsilon$ характерним для прогресивних компаній, стартапів.

3. «Родина». Компанії схожі на велику родину, а керівництво відділів виступає у ролі наставників, до яких завжди можна звернутися за допомогою або порадою.

4. «Ринкова модель». Такий вид корпоративної культури обирають організації, орієнтовані на прибуток. Колектив складається із амбіційних, цілеспрямованих людей, які активно боряться один з одним за місце під сонцем.

5. «Фокус на результат». Достатньо гнучка корпоративна політика,

відмінною рисою якої є бажання розвиватися. Головні цілі - досягнути результату, реалізувати проект, закріпити свої позиції на ринку.

Це основні види корпоративної культури, але окрім них існують змішані типи. Так трапляється 3 компаніями. Які:

- Швидко розвиваються (від малого бізнесу до великого);

- Були поглинені іншими організаціями;

- Змінили основний вид ринкової діяльності;

- Переживають постійну зміну керівництва [5].

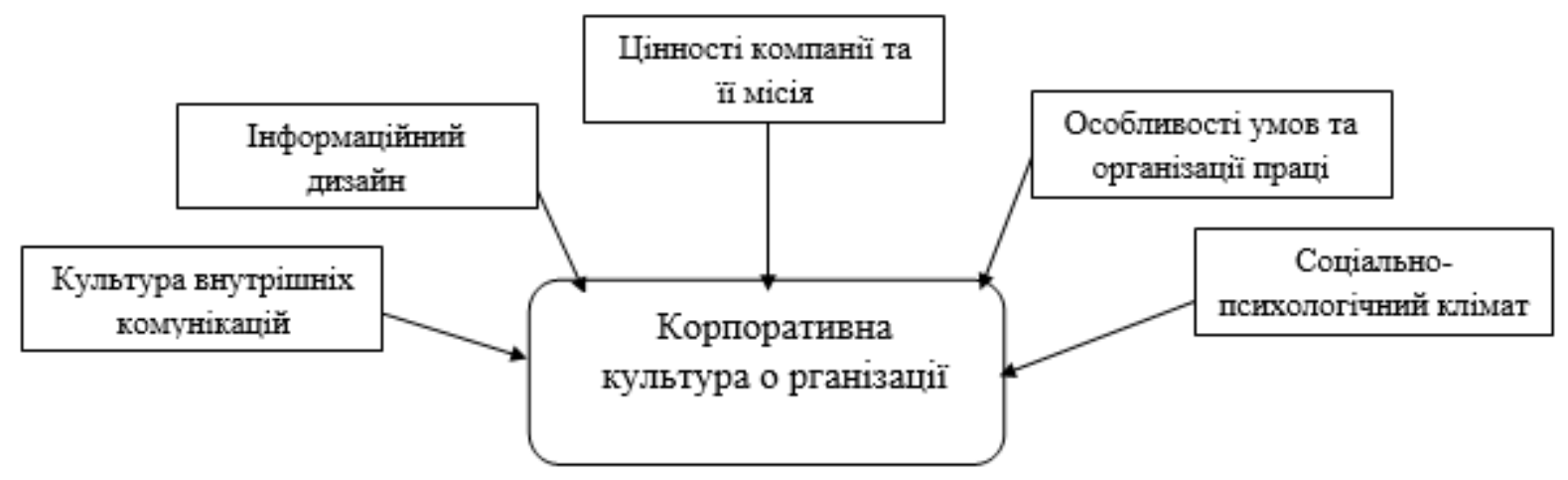

Рис. 1.1. Структура корпоративної культури

Джерело:[6]

Основні принципи побудови корпоративної культури, спрямовані на за безпечення сталого розвитку та економічної безпеки підприємства: 
- створення такої системи найму, навчання та стимулювання персоналу, за якої співробітники розділяють цілі організації і працюють на їх досягнення;

- постійне підвищення професійного рівня керівників вищої та середньої ланки, а також інших працівників;

- організація безперервного обміну інформацією між працівниками для формування уявлення про поточний стан підприємства та зміну ситуації в режимі реального часу;

- розподіл влади i делегування співробітникам повноважень, необхідних для оперативного й адекватного подолання проблемної ситуації;

- поєднання командної роботи 3 особистою відповідальністю співробітника за досягнення поставлених цілей;

- постійний аналіз поточної ситуації та розробка програми швидкого реагування на кризову ситуацію.

Для збереження стійкості свого становища підприємства повинні використовувати гнучкі стратегії ведення бізнесу, а конкурентоспроможність і стійкість компанії визначає людський фактор, що включає в себе високий професіоналізм, відповідальне ставлення до справи, розуміння і прийняття місії та цілей підприємства серед його персоналу. Наприклад, компанія Watson Wyatt провела дослідження індексу людського капіталу, що описує якість роботи з персоналом, на основі даних більше шестисот підприємств різних регіонів світу. Результати дослідження дали змогу зробити висновок про те, що ефективна робота 3 персоналом може забезпечити зрос- тання доходів підприємства на 90\% [3].

Вплив культури на ефективність організації визначається насамперед іiі відповідністю загальній стратегії організації.

Виділяється чотири основних підходи до вирішення проблеми несумісності стратегії й культури в організаціï:

- перший - ігнорується культура, яка серйозно перешкоджає ефективному втіленню в життя обраної стратегї̈;

- другий - система управління підбудовується під існуючу в організації культуру; цей підхід будується на визнанні наявних бар'єрів, створюваних культурою для виконання бажаної стратегіï, i виробленню альтернатив по «обходу» цих перешкод без внесення серйозних змін у саму стратегію;

- третій - робляться спроби змінити культуру таким чином, щоб вона підходила для обраної стратегії. Це найбільш складний підхід, що займає багато часу й вимагає значних ресурсів. Однак бувають такі ситуації, коли він може бути головним для досягнення довгострокового успіху фірми;

- четвертий - змінюється стратегія з метою ії підстроювання під

- існуючу культуру [7].

Механізми впливу корпоративної культури на діяльність організації полягають у тому, що працівники прогнозують розвиток ситуації, щодо якої, керуючись цінностями, оцінюють і вибудовують моделі своєї поведінки та спілкування [8].

Раціональне управління корпоративною культурою компанії надає пози- 
тивний ефект для іiі бізнесу. Зокрема, дозволяє скорочувати затрати не тільки на підбір персоналу, але й на зовнішній PR: члени колективу, які $\epsilon$ провідниками філософії компанії у зовнішній світ, полегшують частину функцій департаменту, який займається PR-політикою організації.

Вплив корпоративної культури на ефективність діяльності підприємства достатньо складно виміряти. Можливо лише виділити деякі ключові аспекти, які впливають на забезпечення успіху, відмітити деякі похибки через відсутність управління культурою і прорахунки в програмі іiі розвитку, указати можливі шляхи зміни несприятливо побудованої культури.

«Nestle» - найбільша в світі компанія - виробник продуктів харчування і напоїв, експерт в області правильного харчування та здорового способу життя. Кредо «Nestle» - робити життя кращим, пропонуючи споживачам тільки якісні і повноцінні продукти. Історія «Nestle» йде корінням у 1866 p. Саме в цьому році Генрі Nestle, вирішивши побороти дитячу смертність, винайшов Farine Lactee - першу в світі молочну суміш для грудних дітей - i приступив до іiі виробництва.

3 тих пір асортимент продукції «Nestle» постійно розширюється, і в даний час налічує понад 8000 торгових марок продуктів харчування, які знають споживачі на всіх п'яти континентах.

Завдання компанії:

- поліпшення якості продукції;

- поліпшення умов праці;

- розвиток нових технологій у виробництві;

- продовження політики, спрямо- ваної на придбання стратегічно вигідних підприємств.

Компанія вважає за важливе будувати бізнес на чітких принципах і раціональному управлінні. Це допомагає підтримувати довіру до бренду Nestlé i знижує ризик вздовж всього ланцюжку створення цінності. В Nestlé Kopпоративні принципи ведення бізнесу регулюють всю роботу бізнесу, формують основу культури, цінностей i стратегії Створення спільних цінностей. Вони регулярно переглядаються Виконавчою радою та погоджуються iз кращими міжнародними практиками, включаючи глобальні стандарти, такі як «Глобальний договір» $\mathrm{OOH}$.

Усі співробітники зобов'язані дотримуватися Корпоративних принципів ведення бізнесу Nestlé, а управління постійно контролює їх застосування та ефективність. Всі ланки компанії щодня забезпечують виконання наших принципів, які втілені у відповідних бізнес-кодах, політиці, процесах та інструментах.

Для того щоб бізнес залишався успішним у довгостроковій перспективі, він повинен створювати цінності не тільки для акціонерів, а й для суспільства в цілому. У «Nestle» корпоративна соціальна відповідальність розуміється як «Створення загальних цінностей».

«Nestle» спочатку була створена як компанія, яка виробляє корисні продукти харчування, тим самим приносячи користь суспільству і заробляючи прибуток для акціонерів компанії і для подальшого бізнесу. Керівники компанії ніколи не розглядали корпоративну соціальну відповідальність як додаткову функцію, це частина стратегії 
ведення бізнесу «Nestle». «Створення спільних цінностей» - в цьому полягає нове бачення корпоративної соціальної відповідальності «Nestle».

«Створення загальних цінностей» це не просто слоган, це ціла концепція, яка має на меті змінити ставлення людей до самого розуміння відповідальності. Разом з тим, концепціїя створення спільних цінностей - це не тільки напрямок діяльності або підхід до роботи, це - спосіб висловити своє ставлення до суспільства і до своєї роботи.

Принципи діяльності компанії «Nestle» (Nestlé Corporate Business Principles), завірені підписами Голови Ради директорів і Виконавчого директора, формують основу корпоративної культури і відображають цінності компанії: чесність, справедливість, повагу до людей і до навколишнього середовища. оновлена версія Корпоративних принципів розроблялася протягом 2010 р. і була переведена на 50 мов. Для того щоб ці принципи стали мірилом діяльності для кожного співробіт- ника компанії, були створені необхідна комунікація і ряд навчальних інструментів. Дотримання принципів співробітниками відстежується за допомогою програми CARE, яка заснована на зовнішньому незалежному аудиті, а також внутрішнім аудитом Групи компаній «Nestle».

У 2010 р. перевірку за системою CARE пройшли 392 підприємства, і ні на одному з них не були виявлені критичні невідповідності вимогам. Кодекс ділової поведінки (Code of Business Conduct) допомагає підтримувати репутацію «Nestle». У новій Політиці взаємин між співробітниками (Employee Relations Policy) викладені міжнародні стандарти і заданий тон відкритого діалогу при вирішенні та обговоренні трудових питань.

До основних принципів діяльності в рамках Глобального договору $\mathrm{OOH}$, а також до принципам про «створення спільних цінностей» відносяться: права людини і трудові відносини, екологічні програми, охорона праці і професійне здоров'я і багато інших [9]

\section{Таблиця 2}

Бізнес-принципи компанії «Nestle»

\begin{tabular}{|c|c|c|c|}
\hline \multirow[t]{3}{*}{ Споживачі } & 1 & $\begin{array}{l}\text { Раціональне хар- } \\
\text { чування та здо- } \\
\text { ровий спосіб } \\
\text { життя }\end{array}$ & $\begin{array}{l}\text { Ми прагнемо підвищити якість життя споживачів, } \\
\text { пропонуючи смачну, здорову їжу та напої та про- } \\
\text { пагуючи здоровий спосіб життя. }\end{array}$ \\
\hline & 2 & $\begin{array}{l}\text { Забезпечення } \\
\text { якості та безпеки } \\
\text { продукції }\end{array}$ & $\begin{array}{l}\text { Ми хочемо впевнитись, що в усьому світі Nestlé } \epsilon \\
\text { втіленням найвищих рівнів якості та безпеки про- } \\
\text { дукції }\end{array}$ \\
\hline & 3 & $\begin{array}{l}\text { Зв'язок із спожи- } \\
\text { вачем }\end{array}$ & $\begin{array}{l}\text { Ми прагнемо до відповідального та надійного } \\
\text { зв'язку, яка інформує споживача, та сприяє здоро- } \\
\text { вому харчуванню. Ми поважаємо приватне життя } \\
\text { споживачів. }\end{array}$ \\
\hline $\begin{array}{l}\text { Права людини } \\
\text { і трудові } \\
\text { відносини }\end{array}$ & 4 & $\begin{array}{l}\text { Права людини в } \\
\text { нашій бізнес } \\
\text { діяльності }\end{array}$ & $\begin{array}{l}\text { Ми повністю підтримуємо «Глобальний договір» } \\
\text { ООН, який впроваджує принципи прав людини та } \\
\text { праці, та маємо на меті надати приклад та забезпе- } \\
\text { чити дотримання людських прав та принципів } \\
\text { праці на всіх етапах нашої бізнес діяльності. }\end{array}$ \\
\hline
\end{tabular}


Закінчення таблиці 2

\begin{tabular}{|c|c|c|c|}
\hline \multirow[t]{3}{*}{$\begin{array}{c}\text { Наші } \\
\text { співробітники }\end{array}$} & 5 & $\begin{array}{c}\text { Лідерство та } \\
\text { особиста } \\
\text { відповідальність }\end{array}$ & $\begin{array}{l}\text { Ми зміцнюємо культуру поваги та гідності, ми } \\
\text { надаємо нашим людям рівні можливості для ро- } \\
\text { звитку, захищаємо їх приватне життя і не допус- } \\
\text { каємо жодних форм переслідування або дис- } \\
\text { кримінації. У той же час, ми очікуємо від наших } \\
\text { співробітників відповідальності, вмотивованості та } \\
\text { поваги до наших цінностей. }\end{array}$ \\
\hline & 6 & $\begin{array}{l}\text { Безпека та за- } \\
\text { хист здоров'я на } \\
\text { роботі }\end{array}$ & $\begin{array}{l}\text { Ми взяли на себе зобов'язання попереджувати } \\
\text { нещасні випадки, поранення та хвороби, пов'язані } \\
\text { з роботою, а також захищати наших працівників, } \\
\text { підрядників та всіх, хто залучений до процесу ви- } \\
\text { робництва. }\end{array}$ \\
\hline & 7 & $\begin{array}{l}\text { Відносини з по- } \\
\text { стачальниками } \\
\text { та споживачами }\end{array}$ & $\begin{array}{l}\text { Ми вимагаємо від наших постачальників, посеред- } \\
\text { ників, підрядників та їхніх співробітників прояв- } \\
\text { ляти відвертість, прямоту та чесність та дотри- } \\
\text { муватись наших сталих, чітких стандартів. }\end{array}$ \\
\hline \multirow[b]{2}{*}{$\begin{array}{c}\text { Постачальники } \\
\text { та споживачі }\end{array}$} & 8 & $\begin{array}{l}\text { Розвиток сільсь- } \\
\text { кого господар- } \\
\text { ства }\end{array}$ & $\begin{array}{l}\text { Ми націлені допомогти сільським громадам стати } \\
\text { більш екологічно стійкими, сприяючи поліпшенню } \\
\text { сільськогосподарського виробництва та соціально- } \\
\text { економічного статусу фермерів. }\end{array}$ \\
\hline & 9 & $\begin{array}{l}\text { Сталість навко- } \\
\text { лишнього сере- } \\
\quad \text { довища }\end{array}$ & $\begin{array}{l}\text { Ми взяли на себе зобов'язання виконувати нашу } \\
\text { діяльність таким чином, щоб навколишнє середо- } \\
\text { вище залишалось сталим, прагнемо раціонально } \\
\text { використовувати природні ресурси, досягти зве- } \\
\text { дення до нуля марнотратства та збитків, сприяємо } \\
\text { використанню ресурсів, що відновлюються або } \\
\text { тих, якими можна стало керувати. }\end{array}$ \\
\hline $\begin{array}{c}\text { Навколишнє } \\
\text { середовище }\end{array}$ & 10 & Вода & $\begin{array}{l}\text { Світ зараз стикається зі зростаючою проблемою із } \\
\text { водою, тому ми взяли на себе зобов’язання сталого } \\
\text { використання води та продовження вдосконалення } \\
\text { управління водними ресурсами. }\end{array}$ \\
\hline
\end{tabular}

Джерело: розроблено авторами на основі [10]

Важливим для компанії є факт залучення нових найманих та нинішніх співробітників до процесу формування оплати праці та винагород. Головним для компанії $€$ цінність та довіра, яку вона приносить тим, хто працює в компаніі; гарні стосунки між менеджерами та співробітниками; визнання та досвід, яким користуються під час роботи у світовій компанії; та можливості вчитися та рости. Nestlé зосереджується на фіксованій оплаті праці, змінній оплаті праці, виплатах, особистісному зростанні та розвитку та життєвому середовищі. У дусі розвитку культури високої продуктивності ці елементи повинні відповідати тому, що цінується працівниками на кожному ринку, i які демонструють, як «Nestlé» прагне надати кожному працівнику можливість рости, розвиватися та сприяти розвитку компанії. Програми загальної винагороди Nestlé повинні бути встановлені в соціальних та правових рамках кожної країни та відповідно до діючих колективних договорів. Відповідальністю кожного керівника $\epsilon$ те, що він має запропо- 
нувати винагороду своїх працівників у рамках політики Компанії.

Навчання $\epsilon$ частиною культури компанії. Співробітників усіх рівнів систематично заохочують покращувати свої знання та вміння. Компанія визначає пріоритети навчання та розвитку. Відповідальність за перетворення їх на дії розподіляється між працівниками, керівниками персоналу та персоналом. Досвід та навчання на роботі $\epsilon$ основним джерелом навчання. Співробітники Nestlé розуміють важливість постійного вдосконалення, а також вільний обмін знаннями та ідеями 3 іншими. Такі практики, як всебічний професійний розвиток, розширення обов'язків та перехресні функціональні команди заохочують працівнимів до отримання додаткових навичок, збагачення змісту роботи та поглиблення відповідальності. Nestlé також пропонує широкий спектр навчальних заходів та методологій для підтримки навчання та зростання кожного. Відвідування програми ніколи не слід розглядати як винагороду, а як складову поточного розвитку. Крім того, корпоративні програми лідерства допомагають розробляти та зберігати розвинену систему менеджменту. Лідери мають можливість відвідувати міжнародні навчальні курси, які будують інтегроване розуміння бізнесу та закріплюють і зміцнюють цінності та принципи «Nestlé», або програми, що проводяться нашими стратегічними партнерами 3 навчання. У Nestlé висока культура продуктивності, яка підтримується різними винагородами та розвитком, $\epsilon$ ключовою для досягнення індивідуальних та корпоративних цілей. Це зумовлено узгодженням чіт- ких та складних обов'язків та забезпеченням того, щоб працівники усвідомлювали, як їхня робота впливає на «Nestlé».

Співробітники регулярно отримують зворотний зв'язок щодо своїх результатів та прагнень до кар'єри через різноманітні інструменти та процеси, такі як процес оцінки ефективності роботи (PE), керівництво прогресу та розвитку (PDG) та $360^{\circ}$ оцінки. Кожен керівник приділяє необхідний час моніторингу цілей та регулярному коучингу працівників протягом року. Кожен працівник, який підтримується лінійним керівником, відповідає за власний професійний розвиток, завдяки чому працівник заохочується висловлювати кар'єрні цілі та очікування у відкритому діалозі.

Зважаючи на важливість, яку «Nestlé» надає культурному розмаїттю, працівникам, які цікавляться міжнародними завданнями, може бути надана можливість працювати в різних країнах.

Компанія прагне забезпечити стабільні умови праці для гендерно збалансованої та різноманітної компанії. Таким чином, Nestlé зосередив увагу на усуненні бар'єрів у прогресі кар'єри для жінок та чоловіків, розробивши більш гнучку систему.

«Nestlé» прагне продовжувати шлях до встановлення рівних i гнучких структур 3 мінімальними рівнями управління та широкими проміжками контролю, що дозволяє розвивати людей, підвищувати ефективність та полегшувати реалізацію «принципів управління та лідерства Nestlé».

Динамічна організація створює атмосферу інновацій та дозволяє людям 
думати різноманітно. У «Nestlé» заохочують людей ризикувати. Помилки можуть бути зроблені, але завжди $є$ бажання виправити i навчитися на них. Організація поєднує силу бренду глобальної компанії з креативністю та знаннями місцевого бізнесу [11].

На думку керівництва, головною конкурентною перевагою компанії $\epsilon$ співробітники. Існуючі в компанії корпоративна культура і система мотивації здатні згуртувати колектив, дати кожному співробітнику можливість досягти будь-яких висот. «Nestle» по праву можна назвати привабливим i відповідальним роботодавцем. Компанія сприяє розвитку молодих фахівців, проводить навчання, організовує практику для випускників ВН3, 3 можливістю подальшого працевлаштування, проводить Дні кар'єри. У компанії є важлива мета - бути кращим роботодавцем, підтримуючи ефективність і нарощуючи різноманіття організації», і для досягнення поставленої мети, виділяються наступні завдання:

- збільшувати різноманіття кадрового потенціалу;

- підтримувати культуру високих досягнень, зі зміцненням взаємозв'язку між результатами робіт і винагородою;

- розвивати лінійних менеджерів для створення умов по розкриттю потенціалу співробітників;

- продовжувати розвиток високоефективної організації для залучення кращих співробітників і їх утримання.

Звичайно, виконанню поставлених завдань сприяють створені компанією умови. Компанія надає своїм працівникам розширений соціальний пакет. Кожному співробітнику оформляється поліс добровільного медичного страхування; тим, чия робота передбачає роз'їзний характер, надається корпоративний автомобіль, оплачується бензин. Частина співробітників мають телефон 3 щомісячним лімітом на безкоштовний мобільний зв'язок. Компанія намагається забезпечувати своїх співробітників всім необхідним для роботи обладнанням, новітніми технологіями та інноваціями $[12,13]$. Для підвищення продуктивності праці i мотивації співробітників, керівництву необхідно отримувати від них зворотний зв'язок. Один з принципів компанії: «вміння почути точку зору співробітника і відреагувати на неї».

Для цього в компанії проводиться опитування, під назвою «Nestle і Я». Це опитування дозволяє визначити задоволеність співробітників по відношенню до робочого процесу. За результатами опитування складається план дій, для усунення помилок, виявляються сильні сторони. Найбільш важлива робота проводиться компанією в рамках реалізації заходів, спрямованих на професійний розвиток персоналу.

«Ініціатива Безперервного вдосконалення» метою якої $є$ розвинути в співробітника прагнення вдосконалюватися і підвищувати дух підприємництва. Регулярно проводяться збори серед співробітників компанії, вони можуть брати участь у вирішенні глобальних проблем компанії. У компанії присутні дві основні програми 3 підвищення і розвитку мотивації персоналу, їх можна віднести до внутрішньої корпоративної соціальної відповідальності. 
Перша програма - процедура PDG (Progress \& Development Guide) складання індивідуального плану розвитку кожного співробітника протягом всієї його кар'єри в компанії. Складання індивідуального плану дозволяє визначити сильні і слабкі сторони працівника, його компетенцію на займаній посаді, і показати майбутній потенціал. Дана процедура містить в собі діалог співробітника зі своїм керівником, який розробляє план дій i заходів 3 розвитку обраних областей [14].

Висновки. Підсумовуючи вищезазначене, можна зробити висновок, що формування корпоративної культури це достатньо кропітливий та складний процес, який залежить від безлічі факторів, саме тому одна корпоративна культура не може стати універсальною для всіх компаній у світі.

Багато учених аналізували типи копроративних культур, які існують, але наразі багато з них вже не $\epsilon$ актуальними, у зв'язку з тим, що дослідження такого поняття як корпоративна куль-

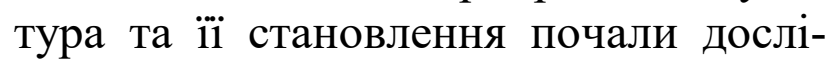
джуватися ще в XX столітті.

Компанія дуже відповідально ставиться до своїх співробітників та створює всі необхідні умови для їх життя та розвитку в компанії.

Одними з таких елементів $є$ :

1. Розширений соціальний пакет (медичне страхування, корпоративний автомобіль та оплата пального);

2. Широкі можливості для професійного та особистісного розвитку в компанії (різноманітні тренінги, курси, практики та стажування);

3. Відкритість до участі співробітниів у розв'язанні важливих питань для компанії, що стосуються глобальних проблем розвитку або певних нових продуктів компанії.

\section{Список використаної літератури}

1. Kozlov V. Corporate culture. M: Alfa Press, 2015., p. 27.

2. Woodcock M., Francis D. The New Unblocked Manager: A Practical Guiide to Self-Development Gower Publishing Ltd; 2nd Revised edition edition (8 Aug. 1996).

3. Babych O. Basic principles of creation of corporate culture as a tool of management. Bulletin of the Ukrainian Academy of Public Administration. 2003. №2 - p. 449-456, p. 452.

4. Malashchenko V. Impact of corporate culture on economic development and enterprise security. Bulletin of the National Academy of Public Administration.

5. Aleshina, I.V. Western and Eastern Business Cultures. URL: www.ippnou.ru.

6. Corporate culture in modern business: types, levels, best examples. URL: http://kirulanov.com/korporativnaya-kultura-v-sovremennom-biznese/.

7. Monastirsky G.L. Organization theory. Ternopil: TNEU. 2014. 288 p. 
8. Grishnova O. Relationship between human values and organizational values in the corporate system. Formation of a market economy: Coll. Sciences. wash. Special. in 3 t. Social and labor relations: theory and practice. K.: KNEU. 2010. Vol. 1. 468 p. 9. Nestle Corporate Social Responsibility. URL: https://www.sbmt.bsu.by/Data_RUS/ContBlocks/01414/Shamalj-Marija-Pavlovna.pdf. 10. The Nestlé Corporate Business Principles. URL: https://www.nestle.ua/sites/g/files/pydnoa316/files/asset-library/documents/corporatebusiness-principles-en.pdf.

11. The Nestlé Human Resources Policy. URL: https://www.nestle.com/sites/default/files/assetlibrary/documents/jobs/the_nestle_hr_policy_pdf_2012.pdf.

12. Bulakh T., Lytvyn O. Innovative Activity of Ukrainian Enterprises under Conditions of the World Economic Space. Norwegian Journal of Development of the International Science. 2018. Vol.2, №16. P. 33-36.

13. Литвин O.Є. Експортний потенціал та можливості українських малих та середніх підприємств на європейському ринку. Актуальні проблеми міжнародних відносин: Зб. наук. праць. Випуск 127 (Частина II). К.: Київський нац. ун-т ім. Т. Шевченка. Інститут міжнародних відносин. 2016. С. 165-175.

14. Kosikova Y., Pirogov N. Corporate Social Responsibility - Traditions of Nestle Russia Company. Young Scientist. 2016. №26. p. 326-328. URL: https://moluch.ru/archive/130/36198/. 